\title{
Of solar collectors, wind power, and car sharing: Comparing and understanding successful cases of grassroots innovations
}

Michael Ornetzeder and Harald Rohracher

\author{
Linköping University Post Print
}

\section{Tweet}

N.B.: When citing this work, cite the original article.

Original Publication:

Michael Ornetzeder and Harald Rohracher, Of solar collectors, wind power, and car sharing: Comparing and understanding successful cases of grassroots innovations, 2013, Global Environmental Change, (23), 5, 856-867. http://dx.doi.org/10.1016/j.gloenycha.2012.12.007

Copyright: Elsevier http://www.elsevier.com/

Postprint available at: Linköping University Electronic Press http://urn.kb.se/resolve?urn=urn:nbn:se:liu:diva-102986 


\title{
Of Solar Collectors, Wind Power, and Car Sharing: Comparing and Understanding Successful Cases of Grassroots Innovations ${ }^{1}$
}

\author{
Michael Ornetzeder ${ }^{\mathrm{a}}$, Harald Rohracher ${ }^{\mathrm{b}}$ \\ ${ }^{a}$ Institute of Technology Assessment (ITA), Austrian Academy of Sciences, Strohgasse 45/5, 1030 Vienna, Austria \\ ${ }^{\mathrm{b}}$ Department of Thematic Studies - Technology and Social Change, Linköping University, 58183 Linköping, Sweden
}

\begin{abstract}
Grassroots activities so far have not been sufficiently appreciated as sources of innovation. Transition processes towards more sustainable socio-technical energy, transport or production systems, however, are hardly imaginable without a broader participation of engaged citizens. This paper presents and compares three cases of successful grassroots innovations for sustainability. In particular we compare the development of wind technology in Denmark, the solar collector do-it-yourself movement in Austria, and the development of car sharing in Switzerland. The paper aims at a better understanding of the preconditions, patterns of growth and change and factors of success of grassroots innovations for more sustainable socio-technical regimes such as energy and transport. In the analysis we focus on dimensions such as the structural conditions and resources of origin, motivations of social actors involved, learning processes and outcomes, competences and activities of those actors, processes of institution-building, and the relationships to mainstream market actors. Based on the empirical background the paper discusses implications for the theorisation of grassroots innovations for greater sustainability and draws implications for further research.
\end{abstract}

\section{Introduction}

The way towards sustainability is often framed as a quest for revolutionary large-scale solutions. However, many of the changes required for such a transformation start out by modifying existing configurations of technologies, services or practices of use at a small scale and eventually growing them into an alternative option to prevailing systems of production and consumption. In innovation research we can find different drivers and contexts for the introduction of such new ideas, concepts, or products for more sustainable systems. The predominantly described case, particularly in economic innovation research is a market-driven development of new products by small start-ups or larger companies. Other cases are more science-driven and are developed by research labs or their spin-offs, as e.g. Garud and Karnøe (2003) describe in the case of wind energy development in the U.S. More recently, with an increasing policy focus on a more sustainable energy generation and use, policy has become an important driver of sustainable technologies by changing regulations and providing economic incentives, such as exemplarily described by Dewald and Truffer (2012) in the case of PV development in Germany. However, less research has been invested so far in

\footnotetext{
${ }^{1}$ Published in: Global Environmental Change 23(5), 2013, pp. 856-867, http://dx.doi.org/10.1016/j.gloenvcha.2012.12.007
} 
innovation processes for sustainability driven by community-based networks (Seyfang and Smith, 2007). Research with a special focus on such grassroots innovations could help shed light on innovative activities outside the traditional realms of science and industry based innovation and improve our ability to collectively profit from ideas and concepts thus far overlooked.

In this article we want to contribute to this endeavour by comparing a number of successful grassroots innovations and thereby enhancing our understanding of the way those initiatives work, the preconditions and contexts they require to thrive, and the phases in the innovation process during which they appear to be most effective. We have chosen three cases of grassroots innovations which have significantly contributed to the improvement and dissemination of sustainable innovations and which already have been well documented in our own research and further literature. The first case is the development of wind turbines in Denmark. Back in the 1970s grassroots activists had a strong influence on the technical design of windmills and promoted local windmill cooperatives to own and operate early electricity producing installations. Today, Denmark has the highest level of wind power penetration in the world and Danish companies are still among the leaders in wind power technology (Observ'ER et al., 2008). The second case deals with the diffusion of solar technology in Austria. For more than ten years do-it-yourself groups dominated the domestic solar heater market causing high diffusion rates and a number of decisive changes in the design of solar technology. Today, Austria takes a similar position regarding thermal solar technology as Denmark does in reference to wind power. Per capita Austria is one of the best equipped countries with solar thermal energy systems in the world (Weiss and Mauthner, 2010). In addition, Austrian solar collector producers are market leaders in Europe. Today, one out of three solar systems sold in Europe comes from Austria. The last example brings us to Switzerland, the country with the most mature market for car sharing in the world (Haefeli et al., 2006). As we will see, organised car sharing started in the 1980s as a private initiative in two regions, set up exclusively by grassroots activists. Without doubt, these are not the only examples of grassroots innovations (see e.g. Smith, 2007, on alternative housing constructions or organic agriculture) nor can they claim to be representative. With a systematic overview and analysis of grassroots innovations in different technology and application fields still lacking, we have chosen these examples as they are empirically well documented, they aim at changing core elements of sustainable energy or transport systems, there is strong evidence that grassroots activities played a major role in developing these innovations and, consequently, because these grassroots innovations have contributed to the strong position of industries and markets for wind power, thermal solar technology, and car sharing in the three respective countries. Moreover, we think that the chosen cases are sufficiently different in their focus and contexts to allow us to identify some common patterns and required preconditions for successful grassroots innovations.

There are certainly different views on what can be regarded a success of grassroots movements. Some initiatives have no ambition to grow and see their aim in contributing to community life, others rather opt for a strategy of helping further initiatives to thrive while maintaining a small size which allows for personal interaction of its members. The group of 
initiatives we have chosen to study, in contrast, appears to see success less in their internal interactions, but rather in their external impact on the existing energy and transport regime and the knock-on effects they have on commercial products or adoption of new technologies and practices. Success from this point of view means that grassroots initiatives contributed to the development and selection of alternatives, e.g. renewable forms of energy as alternative to fossil fuels or nuclear energy, and were able to influence principles of the design in the very beginning in a lasting way. From the perspective of transforming existing energy and transport systems towards greater sustainability these types of grassroots innovations thus may constitute an important and maybe underestimated mode of innovation along with market, science or policy driven innovation processes.

Using these three cases as the empirical background, this paper aims at a better understanding of the preconditions, patterns of growth and change and factors of success of grassroots innovations for more sustainable socio-technical regimes such as energy and transport. In our analysis we will focus on internal dynamics as well as external conditions considering criteria, such as the socio-political context of origin, motivations of social actors involved, learning processes and outcomes, competences and activities of those actors, processes of institution-building, and the relationships to mainstream market actors.

The paper begins with a discussion of literature relevant for better understanding such types of innovation. We draw on former research on grassroots innovations and build on relevant concepts from science and technology studies, including the multi-level perspective approach, the analysis of technological innovation systems, concepts of social learning and the role of users in innovation processes. In the next section a brief description of each case is given, drawing on our own research as well as on secondary case study material. Against the backdrop of our cases we then compare and discuss a number of observations, which aim to improve our theoretical framing of grassroots innovations for sustainability.

\section{Conceptualising and understanding grassroots innovations}

Our cases of wind mills, solar thermal collectors and car sharing are all examples of emerging and evolving socio-technical configurations, i.e. they can be described as new arrangements of technologies, competencies, social practices of design or use, institutions and further elements which have to come together to make these technologies work. These changes and re-arrangements need not be radical; in many cases they are rather gradual improvements in design, shifts in user practices or new meanings and expectations linked to particular technologies. They also have in common that they are part of long-term visions of more sustainable energy and transport systems.

Several concepts exist in science, technology and innovation studies to describe such processes of emerging, expanding and adapting socio-technical arrangements. Of particular use in our case is the multi-level perspective of innovations (Rip and Kemp, 1998) which conceptualises socio-technical stability and change as being shaped by the interaction of different levels of socio-technical structuration. Niches are only loosely structured configurations of technologies and practices and can be seen as testbeds for emerging 
technologies (Hoogma et al., 2002; Smith and Raven, 2012; Geels, 2011); the numbers of actors involved is small, the degree of alignment between elements is low (Geels, 2011), and, we can add, existing rules and standards procedures are put up for negotiation. Sociotechnical regimes, in contrast, represent much more obdurate socio-technical structures such as the present predominantly fossil fuel based and centralised energy system. Such regimes also provide a selection environment for emerging niches and cause many new technologies to fail. Socio-technical landscapes, finally, provide the broader context of deeply entrenched and slowly changing structures in society in which regimes are embedded. Understanding the growth of a niche thus not only requires taking into account niche-internal processes such as the formation of new actor-networks but also interactions between niches, regimes and landscape. Under specific (and rare) circumstances the availability and growth of alternative niche configurations may be an important factor for a more fundamental transformation of existing regimes such as envisioned in the transition towards sustainable energy and transport systems.

Literature on niche-innovation (Kemp et al., 1998; Schot and Geels, 2008) focuses on core processes that are essential to transform inventions and ideas into robust configurations. Accordingly, niches have to support three crucial processes, (a) the articulation and the adjustment of expectations and visions; (b) the building of social networks and the enrolment of a growing number of actors; and (c) learning and articulation processes on dimensions such as technical design, user preferences, or symbolic meanings (Geels, 2011). Moreover, it is of great interest, how local niche experiments eventually contribute to the formation of global niches (Geels and Raven, 2006) and how they transform or are adopted and adapted by dominant regimes structures (Smith, 2007). Niches are protected spaces which may fulfil different roles in shielding innovations from mainstream selection pressures, nurturing such innovations or empowering them to compete with incumbent technologies or transform existing regimes (Smith and Raven, 2012).

As we will argue later, grassroots movements may be functional for various of these core processes of niche development - in terms of network formation, learning and competence building, but also in shielding, nurturing or empowering niche innovations. Of particular interest to us - and not yet systematically studied in the transitions or niche management literature - is the way such niches unfold and develop, how they expand and transform or adapt to existing regime structures and how this process can be driven and shaped by grassroots initiatives. A notable exemption of this lack of studies on the linkages between niches and regimes are Smith's (2007) studies on the niches of eco-housing and organic food in Great Britain.

A further concept frequently used to study the emergence and expansion of new sociotechnical configurations is the analysis of "technological innovation systems (TIS)". TIS can be defined as a "network of agents interacting in a specific economic/industrial area under a particular institutional infrastructure and involved in the generation, diffusion and utilization of technology" (Carlsson and Stankiewicz, 1991). The development of technological fields such as renewable energy technologies (Jacobsson and Johnson 2000) or biogas (Negro et al., 2008), to name just two examples, have been analysed from this perspective. The aim is to 
gain an understanding of the strengths and weaknesses in the performance of these evolving socio-technical systems by assessing patterns of specific activities or functions, such as knowledge development, the formation of markets, the mobilisation of resources or the legitimation of these technologies, and by identifying blocking and inducement mechanisms (e.g. misalignment of regulations, subsidy programmes) in the wider context of these systems. In contrast to the multi-level perspective, TIS analysis is not about systemic changes of existing regimes, but rather about the patterns and conditions of growth for emerging technologies - which however is not in contradiction to the multi-level perspective (Markard and Truffer, 2008). What makes the TIS approach interesting for our analysis is its more finegrained approach to assessing the performance of the evolving systems of solar, wind and transport innovations and thus the ability to estimate the impact of grassroots movements on the development of these social and technical innovations.

As mentioned earlier, the role of 'grassroots innovations' as "networks of activists and organisations generating novel bottom-up solutions for sustainable development" (Seyfang and Smith, 2007, p. 585) has not been widely studied yet. Seyfang and Smith (2007) point out that grassroots innovations differ fundamentally from, as they put it, market-based innovations. By comparing market-based and grassroots innovations, they propose an idealtype framework definition. According to this framework, market-based innovations occur within the wider context of the market economy. In this mode the main driving force to innovate is financial profit, the main actor is the firm, and innovation activities are protected and supported by tax incentives and state subsidies. The main resource base is the income of firms from commercial activity. Grassroots innovations, in contrast, evolve in the context of the social economy of community activities. In this context, main drivers to further develop new ideas are social need and ideology. In this mode, innovation activities try to meet social needs articulated by local actors. At the same time grassroots activities are guided by and committed to more general socio-political ends. Forms of organisation also differ fundamentally. Grassroots innovations are promoted by a wide range of organisational types, including cooperatives, voluntary associations, informal community groups, or social enterprises and build upon a variety of resources including grant funding, voluntary input and mutual exchange, but only limited commercial activity. While we will build on this idealtypical distinction of grassroots and market-based innovations, we also want to draw attention to further modes of innovations, in particular those which are rather driven by science or by policies and regulation, and to mixed modes. On the one hand grassroots and commercial innovation activities may exist side by side, on the other hand particular modes may dominate different phases of the innovation journey. As Sine and Lee (2009) point out in a study on the role of social movements for the development of the U.S. wind energy industry, how social movements and civil society organisations such as Friends of the Earth also shape institutional contexts and social expectations which make it more attractive for commercial firms to move into this field. However, our three cases have their focus more on the immediate involvement of social movements and civil society initiatives in innovation activities.

Due to our interest in the imprint of grassroots initiatives on growth dynamics, institutionalisation and other characteristics of evolving sustainable innovations an emphasis 
of our analysis lies on characteristic phases in the development, dissemination and mainstreaming of such innovations. The early phases of such development, especially if we talk about grassroots initiatives as innovators, are often characterised by an active role of users.

Mackay and Gillespie (1992) have shown that early users are able to play an important role in negotiating meanings and practices related to an artefact. In their role as users, consumers can be active, creative and expressive. In cases of user innovation, the appropriation of technology becomes a broad and transcending activity, obviously "blurring the boundaries between production and consumption" (Oudshoorn and Pinch, 2008, p. 554). Users become 'prosumers' (Toffler, 1980), which means that they are producers of technology, but still well grounded in the knowledge and the day-to-day experiences of ordinary users. To what extent users are able to become active co-designers of technology is indeed dependent on a variety of different factors, covering socio-demographic characteristics, personal skills, structural and cultural conditions, as well as properties of the technology itself. So is it important to bear in mind that there are different groups of users, which largely vary in their power to choose the technology, to acquire skills and authority to use it in different ways, to adapt or modify it, to fix problems, override functions or bypass its outputs, or perhaps to subvert or even reject it (Russell and Williams, 2002). However, if users play an active role in innovations, it is likely that the outcome (design of artefacts, functionality, basic set-up, etc.) will be different from cases without active users involved from the outset, because, in principle, technology designers and producers differ from users in their values, interests, knowledge and expertise (Akrich, 1995). Von Hippel (1998) shows that users have specific local knowledge that could be of crucial importance for defining and solving problems and eventually lead to innovations and new market opportunities.

The main characteristic of successful innovation is that learning in various dimensions occurs over time and, as a consequence, expectations and visions turn into more stable configurations (Geels, 2011). Or, to put it in social constructivist terminology, a situation characterised by interpretative flexibility and variation eventually changes towards closure and reduces space for diverging interpretations. To be successful, innovation processes have to undergo distinctive changes over time. Therefore evolutionary approaches to describe innovation processes put more emphasis on the time dimension of technological innovation, represented by typical phases of development. Weyer et al. (1997) propose a three-stage model of (technological) innovation that covers the stages of emergence, stabilisation and societal diffusion, combining the voluntarism of the social constructivist discourse with the determinism of path-dependency approaches. In this model, innovation paths are actively created and shaped by social groups, while at the same time they are limited by a given structural framework of socio-technical options resulting from previous action (Weyer, 2006).

Drawing on the concept of strategic niche management, Seyfang and Haxeltine (2012) argue with a focus on grassroots innovations that there are three options for successful niches to facilitate the wider diffusion of new socio-technical practices: "by enabling replication of projects within the niche, bringing about aggregative changes through many small initiatives; by enabling constituent projects to grow in scale and attract more participants; and by 
facilitating translation of niche ideas into mainstream settings" (p. 384). For the cases in this paper we might expect that processes of replication, scaling up and translation took place and consequently we also might expect that grassroots actors gradually have lost control over their innovation objects over the years. Hence, success - seen from outside the niche - easily can turn into a problematic development from a grassroots initiatives point of view. On the one hand niche innovations "always evolve and change, losing some of the aspects that originally made them innovative and appealing to early pioneers, and gaining other characteristics that make them attractive and accessible to wider audiences" (Seyfang and Haxeltine, 2012, p. 389) when they successfully diffuse into new contexts. On the other hand translations to mainstream contexts are regarded to be difficult to achieve as "green niches are constructed in opposition to incumbent regimes“ (Smith, 2007, p. 436). Radical niches indeed provide a good environment for sustainability experiments, but at the same time different values and expectations of niche actors make it difficult to de-contextualise, scale up and translate those niche practices to mainstream contexts. We may conclude that for any innovation process but for grassroots innovations in particular there is a trade-off between successful diffusion and innovation control.

Network building activities are of core importance for any innovation process (Kemp et al., 1998). Growing networks of actors not only expand the resource base of niche activities (Geels, 2011), but growing and more stable relations between actors represent the construction of the niche itself (Schot and Geels, 2007). For grassroots innovations we may assume that especially in early phases the composition of networks differ fundamentally from market-based or industrial innovations. While the latter might typically start as coalition between firms, universities and government agencies, grassroots innovations bring together political activists, scientists, citizens' initiatives, unorganised lay people, hobbyists, craftsmen or local entrepreneurs. Future users, i.e. people who will most likely profit personally from the envisioned innovation, are another important group which is typically involved in grassroots initiatives from the beginning. Our cases are good examples. In Denmark, local craftsmen and do-it-yourself builders pioneered small size wind turbines in the early years. In Austria, privately organised do-it-yourself groups dominated the market for domestic solar heaters for more than ten years, and car sharing in Switzerland started as bottom-up initiatives by small circles of friends.

A final conceptual issue we shortly want to touch upon is the question of space and scale in sustainability transitions. There has been concern about the 'spatial blindness' of sociotechnical system transitions concepts (Hodson and Marvin, 2010) and an increasing body of literature engages with the role of space in socio-technical change, the impact of particular regional or urban contexts, the interactions across scalar levels (e.g. regional-national) etc. (Truffer and Coenen, 2012). Although it will not be at the centre of our analysis, spatial contexts obviously play an important role in our cases of grassroots innovations which all have developed in different regions and have been embedded in local traditions and preexisting networks. The growth of these niches beyond their regional origins also meant establishing networks across different regions and the involvement of national level governance structures. Particularly grassroots innovations are often deeply embedded in local 
communities and depend on the spatial proximity of their members (though not exclusivelyinternet communities may work in similar ways).

\section{Three cases of sustainable grassroots innovations}

Let us now turn to the three cases we have selected to explore structural conditions and internal dynamics of successful grassroots innovations. Danish windmills, Austrian solar collectors, and Swiss car clubs are outstanding examples. Especially in early phases of development, the process of innovation in these cases mainly was driven by self-organised, voluntary civil society action. The role of grassroots actors as well as the impact of their activities is well documented in literature. In this section we describe each case briefly, drawing on our own research and on secondary literature. Based on these descriptions, we compare and discuss critical aspects of these cases in the following.

\subsection{Development of modern wind turbines in Denmark}

In Denmark, the development of modern, electricity producing wind turbines started in the early 1970s as an outcome of the societal conflict about the use of nuclear energy (main sources for this case: Jørgensen and Karnøe, 1995; Danielsen and Halkier, 1995). As energy prices jumped in the course of the first OPEC oil embargo in 1974, one of the Danish electricity companies decided to build a first nuclear power plant in the Jutland region. Shortly after this announcement, grassroots activists founded the Organisation for Information about Atomic Power (OOA), a nation-wide citizen's initiative to stop nuclear power. According to Danielsen and Halkier (1995), the OOA applied a strategy, as they put it, in 'two lines', from the beginning. The OOA not only was strictly against nuclear power, at the same time OOA activists promoted and supported the development of alternative energy technologies to show that practical energy alternatives are within reach. As a major consequence of this pro-alternative energy approach, the OOA joined forces with a group of established scientists to prepare the first Alternative Energy Plan for Denmark.

In 1975, a subgroup of the anti-nuclear power movement established another association, the Organisation for Renewable Energy (OVE). Danielsen and Halkier (1995) characterise the OVE "as a classical grassroots movement of the 1970s" (p. 63). Activists were organised in local groups throughout the country. The OVE's main mission was to promote the practical development of alternative energy technologies. Early on, the OVE started to organise regular meetings to connect existing local activities and to improve mutual exchange and learning. A first meeting on wind power technology (Vindtræf) took place in November 1976. This forum quickly developed into an informal network to discuss and exchange technical issues of wind turbines. Participants at these meetings were "self-builders, craftsmen, architects, engineers, teachers from folk high schools and researchers" (p. 64). In the early days these kinds of participants dominated the wind power meetings. Later, after the government started to support research on wind power, people from test stations and the emerging local industry joined these meetings, too. 
Already in the mid 70s a reasonable number of pilot plants and prototypes of windmills were available all over the country. These experiments were able to build on the long tradition of practical engagement with windmill technology in Denmark going back to the 18th Century. Experimentation in technical designs resulted in a large variety of solutions. While most applications designed for electricity production at that time experimented with small sized generators typically ranging from 20 to $50 \mathrm{~kW}$, a single initiative aimed to exceed these dimensions by building the world's largest wind turbine thus far. According to Danielsen and Halkier (1995), the so-called Tvind Mill project was initiated by a group of wind power enthusiast from the folk high school at Ulfborg. Like most other initiatives at that time, even this extremely huge construction was set up as a low budget bottom-up initiative. Volunteers from all over Denmark were involved in the construction of the prototype with a projected capacity of 2 MW. The turbine was completed in 1978 and produced electricity until 1993. The impressive dimensions of the construction, the achieved energy output and the fact that it worked quite well for several years provided substantial arguments to support wind energy at the political level. "The Tvind schools showed that wind power was able to contribute to the production of electricity and thereby beating the arguments against wind power of the electricity companies" (Danielsen and Halkier, 1995, p. 65). In addition, the Tvind Mill prototype made use of a number of technical features which were later adopted by early producers of wind technology, e.g. the turbine in Ulfborg was equipped with fibreglass blades, becoming the standard design of industrially produced wind turbines.

According to Jørgensen and Karnøe (1995), in 1978 the first phase of innovation, dominated by grassroots entrepreneurs and do-it-yourself builders, passed over to a second phase characterised by early industrialisation and home market development. In 1978 two professional interest groups were founded: the Association of Danish Wind Turbine Owners and the Association of Danish Wind Turbine Manufacturers. Also in 1978 the first national research programme for wind energy was launched and, as a part of this programme, a test station for small wind turbines at Ris $\emptyset$ started operations. Larger companies such as Vestasnow the world's largest manufacturer of wind turbines, then a manufacturer of agricultural equipment and cranes - started with the serial production of wind turbines in 1980. Other Danish manufacturers, such as Bonus, Nordtank or Micon, followed shortly thereafter (Danielsen and Halkier, 1995).

Although research institutes and firms became leading actors on the production-side, early user-owners still had a significant impact on the further development of the technology. The Association of Danish Wind Mill Owners applied for concrete design features that would improve the safety and reliability of wind turbines (Tranaes 1997). Based on these inputs manufacturers produced an advanced improved double braking system, which is, in principle, still in use today. The association was also the main driving force regarding the development of rules and standards for grid connection of wind turbines. Moreover, from 1980 on, they published performance data (like breakdowns or output) of installed wind turbines on a monthly basis. This turned out to be an effective strategy to increase market transparency, which indirectly helped to improve the quality of industrial products, too (Garud and Karnøe, 2003). 
Besides the influence on the technical design, grassroots activists and user-owners of wind turbines also played a crucial role regarding the early dissemination and implementation of the technology. Until the mid-1980s, wind turbines were almost exclusively run by private owners, which in most cases were organised in the form of local cooperatives. Data from 1992 shows that 75 percent of installed wind power capacity was controlled by such cooperatives at that time (Danielsen and Halkier, 1995, p. 21). The first windmill cooperative was founded in 1980. Using this as a model during the 1980s, a growing number of cooperatives were founded. Danielsen and Halkier (1995) point out, that in many cases former anti-nuclear activists were involved in these local initiatives. Based on ideals of traditional rural guilds, the wind power cooperatives applied democratic principles, which among others enabled members to discuss questions regarding the acceptance of wind technology as well as to influence the search of appropriate installation sites. Another important rule of windmill cooperatives stated that membership is to be restricted to local people. Using these principles, promoters of wind power were able to overcome local scepticism and resistance, in many cases resulting in a growing domestic market for wind power (Danielsen and Halkier, 1995, p. 135). How successful this strategy in fact was, can be shown using data from the year 1996. At that time, 2.150 windmills were operated by local cooperatives, whereas the overall property was owned by 54.844 cooperative members (Tranaes, 1997).

\subsection{Diffusion of do-it-yourself solar collectors in Austria}

In Austria, solar water heaters appeared on the market for the first time in the mid 70s (main sources for this case: Ornetzeder, 2001; Ornetzeder and Rohracher, 2006). At that time, alternative forms of energy in general and specific products like solar water heaters became attractive due to the turbulent situation on the energy market caused by the first OPEC oil embargo in 1973. Solar energy was promoted as an alternative to oil, and solar water heaters were the first available product for homeowners to meet this new demand. In these early years, solar collectors - the energy converting part of solar water heaters-were mainly produced by small manufacturers supplying local markets. These early-stage products showed serious technical problems and offered poor value for money. A first product test organised by the Austrian Consumer Association in 1977 concluded that all available products on the market were still immature and too expensive (Verein für Konsumenteninformation, 1977). Despite these evident problems, after the second oil crisis in 1978, the market for solar water heaters again showed strong growth rates. However, after the energy prices levelled out (and even fell) from 1980 onward, the market for solar collectors in Austria as well as in Europe almost entirely broke down. As a consequence many domestic manufacturers stopped the production of solar collectors (Ornetzeder, 2001).

Already in the late 1970s, solar collectors were produced by do-it-yourself builders, but most of these attempts remain isolated private initiatives (Ornetzeder and Rohracher, 2006). A first group of do-it-yourself builders with a larger number of participants was founded in the course of an ecological co-housing project in a rural village near the city of Graz in 1983. Based on these experiences, and shortly thereafter, two more groups with a total of more than 
100 participants were formed by interested homeowners from neighbouring villages. The activities of these first groups attracted a great deal of attention, including reports in local newspapers which in turn led to further demand for solar technology in the region. Interested parties began to invite participants from the initial groups to share their experiences and give technical and organisational support. As further groups started to assemble solar collectors, a first set of simple tools, construction drawings and technical descriptions evolved. This novel practice of the grassroots solar collector production became more stable and standardised with each new group. Experiences and important information were documented in a written manual, supported by regional development funds. In the following years this special form of the do-it-yourself approach (see Ornetzeder, 2001) became increasingly popular and a larger number of groups spread out all over the country.

Once the activities of do-it-yourself groups drew nationwide attention, the remaining commercial suppliers of solar heater equipment were strongly against this, labelling the work of the do-it-yourself groups 'botched jobs'. However, contrary to these initial fears of producers and installers the climate of opinion changed as it turned out that the activities of the grassroots initiatives stimulated the market for solar heater systems in general and, as a consequence, commercial manufacturers recorded significant growth rates during the 1980s. It seems that extensive lecturing activities of grassroots people, in most cases former group leaders, helped increase the awareness for solar energy technology in general. It also turned out that solar collectors produced in do-it-yourself groups were attractive for new groups of customers due to lower costs. A large share of do-it-yourself group participants came from rural areas, from households still equipped with old-fashioned, manually operated wood-fired central heating systems. In those cases, the installation of solar heaters not only promised environmental benefits but also brought about a significant gain in personal comfort (Ornetzeder and Rohracher, 2001).

After several years of voluntary dissemination activities, including about 50 do-ityourself groups with more than 1.000 participants, former group leaders founded the Association for Renewable Energy (AEE) in 1988. This step provided an institutional basis to bundle previous activities while at the same time helping to widen the focus from thermal solar to other forms of renewable energies. Establishing an association created the opportunity to act as a formal interest group for poorly connected groups. Moreover, from then on it was possible to get financial support from the public sector for certain services such as training seminars, consulting, and the like. Shortly after the association was established, previous grassroots activities received various awards (Austrian Environmental Protection Award, European Conservation Award, the Austrian State Prize for Energy Research). Today, activities of the AEE focus on applied research and technical planning and an affiliated commercial company was established some years ago. Former grassroots activists are still active in leading positions. Based on many years of expertise with solar technology, the research branch of AEE is one of the leading institutes of solar technology in Europe. Only recently were they involved in the development of the world's largest thermal solar project in Saudi-Arabia (OTS/BMVIT, 2012). 
The grassroots activities brought about a technically simple but highly reliable and cost effective type of collector, continuously improved on the basis of practical experience over a period of more than 10 years. Applying this technology between 1983 and 1997, more than $400,000 \mathrm{~m}^{2}$ of collector surface were produced and installed all over the country (Faninger, 2000). For many years, the collector produced in do-it-yourself groups was the marketdominating type. In some cases, the design of this collector was adopted and distributed by commercial manufacturers.

Grassroots activists also developed a new method to integrate solar collectors directly into the roof (Ornetzeder and Rohracher, 2006). Roof-integrated collectors were not available on the market in the 1980s, but for do-it-yourself builders this method promised a number of advantages. It was cost-effective because an expensive metal casing for the collector was no longer necessary and in most cases roof-integrated solutions showed aesthetic advantages, too. After some field-tests with pilot-applications to evaluate the reliability of the new method, roof-integration soon became the standard option in the do-it-yourself community. The roof-integrated collector helped to improve the acceptance and diffusion of solar technology in general and was later adopted by commercial suppliers. One of the current market leaders (Sonnenkraft Österreich Vertriebs Gmbh) started business with a copy of this type of collector in 1992. Today, roof-integrated installations not only dominate the domestic market, technical principles of roof-integration also prepared the ground for the development of façade-integrated collectors enabling vertical installations.

First practical attempts to use surplus solar gains to meet space-heating needs can also be traced back to grassroots experiments. While R\&D projects were focussing on seasonal storage systems, do-it-yourself builders gained experience in small-sized combination systems. In the 1990s, when the thermal quality of new residential buildings improved substantially, these concepts became cost-efficient and increasingly popular. According to estimates, up to 50 percent of the annually installed solar systems in Austria are designed to serve both, hot water and space heating needs since the mid-1990s (Haas et al., 2001). As a consequence, Austria represents the worldwide leading market for semi-solar room heating systems today.

\subsection{Development of organised car sharing in Switzerland}

The development of organised car sharing in Switzerland is our third example of grassroots innovations in the field of sustainability. Truffer (2003) defines organised car sharing as "a specific way of gaining access to means of travel and of organising individual transport" ( $p$. 143). 'Organised' also means that it is different to widely used informal ways of sharing automobiles in families or neighbourhoods. Organised car sharing offers a variety of vehicles to members of the organisation and thereby allows for the decoupling of ownership and use of cars. Positive environmental effects may result from the potentially higher degree of utilisation of the existing stock of vehicles and of eventually changed user mobility-patterns. In fact research shows that on average the membership in car sharing organisations leads to a reduction of annual distances travelled by car (Behrendt, 2000). As a transport innovation, car 
sharing holds the promise to play a part in a more flexible, intermodal and hence sustainable mobility system.

According to Shaheen et al. (1998), the first documented car sharing initiative also started in Switzerland, in the city of Zurich in 1948. It was organised as a cooperative and mainly motivated by economic reasons. Similar initiatives to initiate car sharing on a more formal basis in other European countries are documented, however, none of them led to stable innovations. Car sharing as it is now well established in Switzerland and many other countries in the world started in 1987-independently of each other-in two different Swiss regions. Truffer (2003) shows that both initiatives started as private forms of car sharing among existing circles of friends. "Being convinced of the economic and environmental benefits of their system," states Truffer, "they wanted to facilitate the adoption of their model by other communities" (p. 143). The first initiative, called ShareCom, was based in the Zurich area, and the second one, ATG (Auto Teilet Genossenschaft), started in the region of Lucerne. In the beginning, both initiatives were based on voluntary engagement by members. And in both cases, the activists decided to set up a formal cooperative early on. According to Truffer, "in Switzerland, this form requires a minimal amount of funds and guarantees a high degree of participation in collective decision processes" (Truffer, 2003). In the following years both cooperatives experienced exponential growth rates. It is interesting to know that although both initiatives started in the same year and followed a bottom-up approach, they developed quite different organisational cultures applying fundamentally different management philosophies, having a different understanding of their innovation, and drawing on a radically different definition of the relationship between users and organisation. ShareCom was much more community-oriented, i.e. at least in the first years members themselves were responsible for a variety of tasks - from accounting to maintenance of vehicles. ATG, however, from the beginning was much more service oriented (Hockerts, 2004). Negotiations over a possible merger of the two cooperatives, shortly after they became aware of each other in 1989, were quickly abandoned mainly due to these cultural differences. Not until 1997, as a result of internal management problems and pressure from the market, did ShareCom and ATG merge into Mobility Car Sharing Switzerland. The newly formed company again was legally constituted as a cooperative, however, internally run as a professional service enterprise. Mobility Car Sharing Switzerland soon offered car sharing throughout the whole country. Today, with 2350 vehicles at 1200 locations and approximately 93,700 customers, Mobility Car Sharing is the largest car sharing provider in Europe (Mobility car sharing, 2011; Haefeli et al., 2006).

Shortly after organised car sharing started in Switzerland, similar initiatives were launched in other European countries, Canada and the United States. Today, car sharing is offered in most European countries. On a quantitative basis, the largest market is Germany where currently about 110 car sharing organisations with 158,000 customers are active. Recently, even a large German car manufacturer launched its own car sharing programme (car2go) which is now available in a few cities in Germany, France, Austria, and the US (Daimler, 2012). 
In his case study, Truffer (2003) shows that, in the Swiss example, grassroots activists exclusively developed organised car sharing following a step-by-step process. "In the beginning," Truffer says, "the system consisted of nothing more than users who shared a car. With time, organised car sharing grew into a professional service enterprise" (p. 142). In this process, early users played a crucial role. On the one hand they gradually developed and improved the system, starting from simple informal agreements while, on the other hand, promoting their innovation. In the beginning, to manage the start off, the development was mainly financed by its users. In this phase, members provided resources, in terms of membership fees and private loans with low interest rates, and voluntary work, which helped keep administrative costs (booking, billing, maintenance, etc.) at a low level. New members were recruited by word of mouth. The early membership-structure relied mainly on existing social networks helping to reduce uncertainties for new members. The active involvement of a large number of early user-providers "created a favourable environment for the technology to prosper and for the promoters to learn how to deal with a rapidly expanding market" (p. 148). In this phase, early users had substantial influence in the articulation of the car sharing qualities. The service was able to develop in a gradual learning process, addressing questions of service quality, user expectations, or the public image of car sharing, but there was also space to rethink and change individual mobility patterns. Later, when the two cooperatives merged into Mobility Car Sharing Switzerland, roles of users and providers became more differentiated but providers were able to build on a set of already stable configurations.

\section{Discussion of case studies}

In the following we discuss and analyse the cases of successful grassroots innovations in comparison. We follow typical phases in a roughly chronological order covering the contexts of origin, periods of growth, stabilisation and closure and discuss how and in which way these grassroots innovations could gain wider influence.

An important commonality of the grassroots innovations described is that they were not driven by financial motives, but to a large extent were fuelled by wider social discourses about a more sustainable energy use. It is typical that grassroots activities always started in opposition to something and/or as a solution to a perceived problem. In two of our cases the oil price fluctuations in the wake of the first OPEC oil embargo in 1973 led to a series of different reactions and activities of political, corporate and other actors including various grassroots initiatives. The Danish anti-nuclear movement, as direct reaction to a fundamental change of the national energy policy can be traced back to the shock on the oil markets just as the abrupt discovery of solar energy as a possible solution to the depletion of fossil fuels was made. In Austria, first do-it-yourself activities to build solar collectors in the late 1970s were initiated in a public presentation on the potential of solar energy given by a well-known scientist, recently returned from a study trip in the U.S. The relevance of external factors becomes even more important when we consider that in all three cases a number of similar activities started at about the same time. Grassroots experiments with wind turbines were 
undertaken by many actors in a variety of contexts and places; in Austria, do-it-yourself activities with solar collectors were not restricted to those which later became the organised group-building principle; and in the case of car sharing we can see that two very similar initiatives started at the same time independently from each other. In terms of technological innovation systems (TIS) analysis much emphasis is put on the function of legitimation in the early growth phases of these socio-technical systems.

Grassroots initiatives depend on and make use of a number of other specific structural resources, like national or local traditions, pre-existing practices and competences, and small interpersonal networks. Those specific compositions of structural elements may explain why grassroots innovations emerge and grow only in specific territorial spaces while the same landscape factors are not able to initiate grassroots activities elsewhere. As we could see in the solar case study local traditions in the specific form of neighbourly help, still regularly practiced during the fruit-harvesting season in the Austrian region where the first do-ityourself groups started, served as a reliable model and organisational resource for early grassroots actors. In a similar way, the traditional culture of cooperatives in Denmark and Switzerland gave grassroots innovations well-proofed means of organising collective action. Even specific personal skills, necessary e.g. to tinker with and construct technical devices like solar collectors or small wind turbines, depend on pre-existing communities of practice as represented by farmers or local craftsmen. Another important resource that is crucial for grassroots innovations could be found in our cases too. Especially in the beginning all of these activities almost completely were dependent on the voluntary and unpaid engagement of interested individuals. Obviously, various pre-existing structural conditions given in a specific local way are necessary for opening creative spaces of experimentation and learning. These pre-existing structures thus provide an important basis for the early formation of networks and can be regarded as important resources (less in a financial sense, but in the form of social capital, voluntary working hours, etc.) for the further growth of these sustainable innovations.

Also motivations to start off grassroots initiatives certainly were induced or at least reenforced by developments at the landscape level. Pioneers in all three cases were ideologically connected to the environmental movement and, more specifically, to global (oil crises) as well as national (Waldsterben) discourses. However, it appears to be important that even the early networks brought people with a range of different motivations together. Besides politically motivated activists, we found people with more individualistic reasons to participate, either interested to profit personally as users of new technologies or services in the future or, in some rare cases, driven by economic interests, i.e. people who wanted to start their own business. Other participants were motivated by seeking the company of like-minded people and the feeling of being useful, while still others were mainly interested in tinkering and problem-solving activities. Similar to the work of Hess (2007) on the influence of social movements on scientific and technological innovation in the U.S. our cases show a diverse combination of motives and drivers ranging from individual and perceived social needs to ideological ends. In particular, the prospect of personally profit from the envisioned innovation as a user was-especially in the cases of solar collectors and car sharing - of decisive importance. Another motive to take action was especially effective in the wind 
turbine case. Some local people started to engage with wind technology as a reaction to thefrom their point of view - arrogant attitude of pro-nuclear representatives (Danielsen and Halkier, 1995). Based on that finding and in line with literature on communities of practice (Wenger, 1998) we may make the case that diversity in pioneering networks is an important pre-requisite for further growth, development, and learning. And, we may assume that it needs both problem-solving and mission-oriented types of participants for grassroots activities to persist as a space for innovation. Regarding the composition of pioneering networks and the personal motivations and commitment of individuals involved grassroots innovations clearly differ from other forms of niches for innovation.

As Seyfang and Smith (2007) phrase it, the challenge for grassroots innovations after start up "is to survive and keep going" (p. 596). In order to facilitate core processes for innovation such as learning and articulation of various dimensions (Geels, 2011) 'momentum building' is of significant importance to any innovation process. As we can see, the pioneering actors in our examples were sufficiently successful in networking and expanding the resource base. In the cases of solar collectors and car sharing, momentum building was mainly a demand driven process; people who became familiar with the activities were interested to join one of the do-it-yourself groups or to become a member of one of the car clubs. In the wind technology case, isolated and geographically distributed actors were interested to get in touch and share experience and knowledge. These dynamics brought about a first burst of growth.

Formal institutionalisation and organisation building seems to be a next crucial step in the development of grassroots innovations. On the one hand this strengthens the commitment of participants and thus provides a more stable basis to consolidate and re-arrange previous activities. On the other hand and even more important, a formal structure helps to gain better access to further resources. The financial situation can be improved by setting up a framework that allows charging membership fees which actually was the case in all our three examples. In addition, a legal and non-profit organisational structure allows gaining public funding and sponsorship. Beside the improvement of the financial basis, institutionalisation also provides better access to social capital, e.g. by means of public awards or improved attention in the media, which in turn can help to attract new members.

With their roots in civil society pioneering actors in all three cases decided to set up democratically governed, not-for-profit cooperatives. Democratic principles therefore became (even more) part of the rule set that structured the further innovation activities. As a consequence, learning processes mainly became organised as negotiations and knowledge and information mainly were treated as an open source. For instance, the decision to switch from on-top installation to roof-integrated collectors was not only based on several testinstallations, it also was accompanied by an extended discussion between former group leaders. And, even more important, this open handling of information was not limited to members of the grassroots networks. Knowledge and other outcomes of grassroots activities were freely available to any other actor and was met with great interest by companies in the solar collector and wind technology cases. The Swiss car sharing initiative in turn became role a model for many similar initiatives all over the world. 
Table 1 records a number of outcomes and impacts caused by the analysed grassroots innovations. According to this list, grassroots action was able to produce new or improved technical designs, to support the integration of elements to existing infrastructure systems, to develop a completely new service system, to open up new market niches, and to influence regulation and policies. In order to do so, grassroots innovations were able to facilitate multiple learning processes. Besides the democratic structure which definitely represents an important aspect of learning environments created by grassroots innovations, learning is obviously affected by the specific composition of actors who typically represent a wide range of complementary competencies, skills, and expertise. Grassroots networks may have limited access to scientific knowledge and expertise as well as to modern means of production, but they work, as our examples show, excellently in creating new use practices and lead markets. Network partners as well as the members of co-operations represent valuable use cases that are essential for any innovation process. These early users have specific local knowledge and make first hand experiences with new and therefore immature solutions. Due to the high identification with the envisioned innovation and broader socio-political mission involved these users are willing to engage with unsolved problems and, as almost inevitable in early phases of development, poorly performing technology. Our cases show that learning happened mainly in a bottom-up manner, typically framed in the literature as learning by using, doing, and interacting. Practical experiences with still deficient technological solutions helped to identify numerous opportunities for improvement. Garud and Karnøe (2003) for example conclude for the Danish wind turbine case that the large number of "dispersed installations functioning under different conditions of use created multiple learning opportunities" (p. 288) which later became an important source for industrial producers of wind technology. A quite similar picture is drawn by the case of solar collectors in Austria. Technical problems as well as ideas for improvement were efficiently communicated via the established network of former group leaders. The fast growing number of installations offered an effective environment for technical variation and selection.

\begin{tabular}{llll}
\hline & Wind turbines & Solar collectors & Car sharing \\
\hline Geographical area & Denmark & Austria & Switzerland \\
\hline Main time period & 1974 till 1985 & 1983 till 1992 & 1987 till 1997 \\
\hline Landscape factors & 'Oil crisis' & 'Oil crisis' & Public discourse on forest \\
& Danish nuclear power policy & Tradition of neighbourly help in & degradation (Waldsterben) \\
& Long tradition of windmill & rural areas & Practice of private car sharing \\
& development & Large number of old-fashioned & Long tradition of cooperatives in \\
& Long tradition of local cooperatives & heating systems in rural & Switzerland \\
& & households & Urban context (public transport, \\
& & & lack of car parking, traffic jams) \\
\hline Main motives of & Demonstrate practical alternatives & Ecological motives & Economic motives \\
activists & to nuclear power & Enhance personal comfort & Environmental concerns (reduction \\
& Show 'arrogant nuclear power & Gain cost-effective solar collectors & of local emissions and oil demand) \\
& representatives' how things are & Mission-oriented motivations (e.g. & Entrepreneurial motives \\
& done (differently) & Support renewable energy in & \\
& Contribute to national education & general) & \\
& Entrepreneurial and economic & & \\
& motives & & Foundation and development of the \\
\hline
\end{tabular}




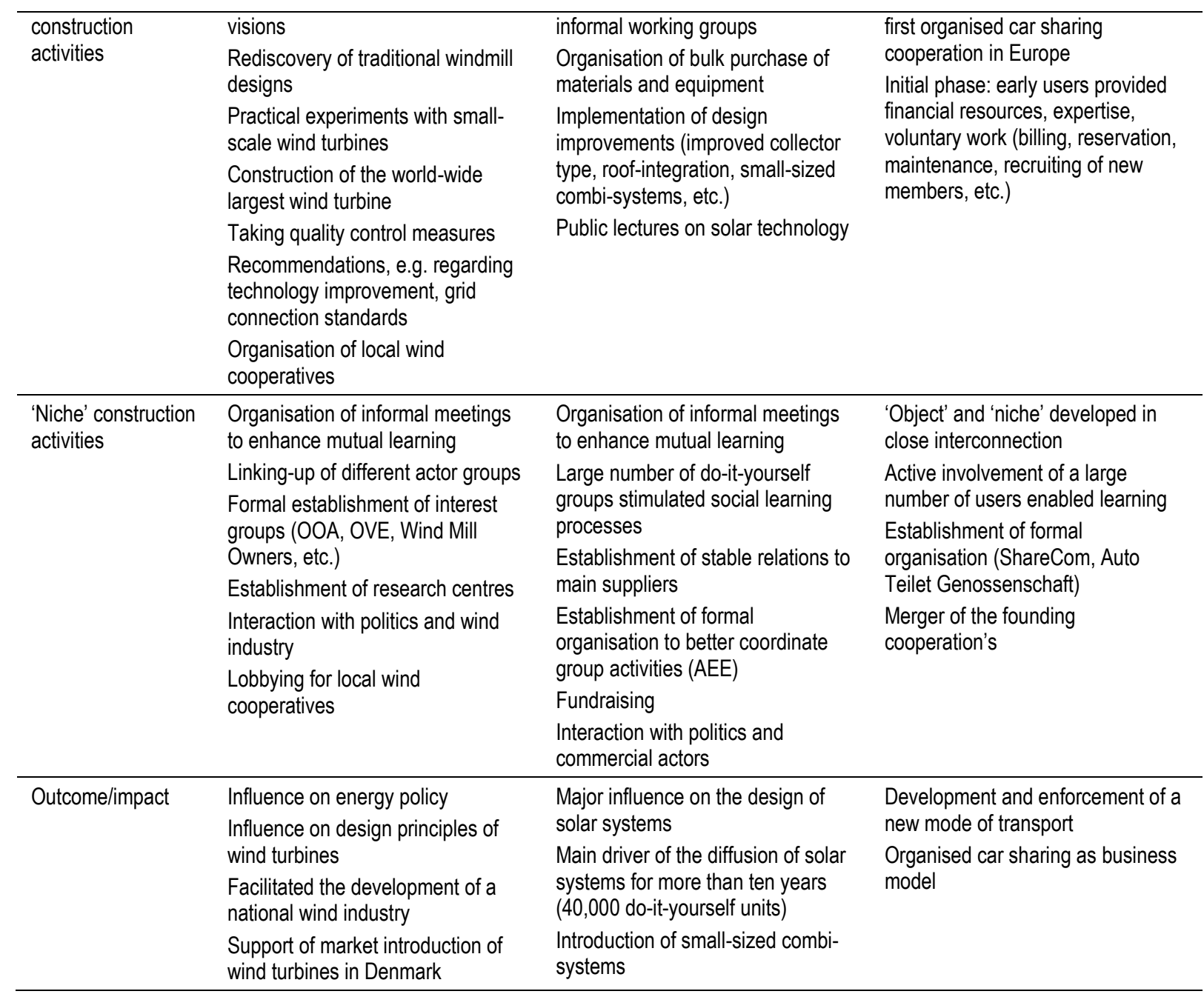

Table 1. Summary of case study analysis

Moreover, the dominant position of users also helped to articulate newly emerging symbolic meanings and to smoothly fit technology into existing local contexts. The case of car sharing shows the extent to which the composition of actor networks may influence the development path of the respective innovation. Although both networks were dealing with the development of organised car sharing, different compositions of pioneer networks eventually led to fundamentally different visions of car sharing and organisational cultures.

Our cases suggest that the wider influence they eventually could gain was, in fact, based on what may be called 'broadening the niche'. In all three cases processes of replication, scaling up, and translation into mainstream settings could be observed, albeit each case shows different characteristics. Replication of projects was the main resource for experimenting and learning in the wind turbine case where a large number of divergent technical solutions were tested under different local conditions. Scaling up in a technical sense was tried and tested by grassroots activists in the very beginning but remained a single attempt until industrial producers defined scaling up as the main commercial strategy for wind energy. However, to some extent grassroots actors were able to play a role in translation processes, e.g. regarding safety issues of larger turbines. As in any innovation process with a growing number of actors in the field the capability for pioneering actors to control translation processes decreased. In 
the solar case replication was the dominant mode for many years and translations of core principles did happen with only minor changes, whereas scaling up thermal solar systemsregarding both the production of collectors and large scale installations — was predominantly a strategy applied by market and industrial actors from the mid 1990s. Organised car sharing started in a mode of replication as two independent initiatives. Shortly after the core concept had been replicated in many other European countries. Scaling up indeed was the main strategy in the car sharing case. As a result of severe internal debates about the future of the organisation after the merger of the two initiatives Mobility Car Sharing Switzerland decided to strive for a commercial service company.

After reaching a certain stability in niches mainly defined by grassroots actors, the emerging development paths became attractive for other actors, too: existing as newly established research institutions, technology producers, retailers and interest groups, or as in the case of car sharing, former grassroots initiatives transformed into profit-oriented professional services providers. Over the years some grassroots actors disappeared while others specialised in specific roles (like research and planning in the solar case or representation of interests in the wind turbine case). Along with many other activist groups of this generation of grassroots practitioners the social movement structure was transformed into more institutionalised settings (Eyerman and Jamison, 1991). However, innovation journeys in our cases were substantially shaped over a period of several years by grassroots activities which influenced not only the technical design but the way the innovations provided were used and embedded in local contexts and temporarily dominated the mode and dynamic of their wider diffusion (organised do-it-yourself groups, owner cooperatives). Although processes of translation to mainstream contexts were difficult to control for pioneering actors in all three cases, major characteristics of the new products and services can be traced back to early phases of learning and experimenting by grassroots actors dominated niches. By broadening their networks and mainstreaming and translating the new socio-technical configurations to other contexts and actor networks, wind power, solar technology, and car sharing developed into stable market-niches in their respective home markets. They did not replace incumbent socio-technical regimes but at least in their domestic contexts the resulting innovations are now considered as promising elements of a more sustainable energy and transport system.

\section{Conclusions}

The three cases of grassroots innovations we have studied all exhibit remarkable similarities. They have been selected on the basis of their success in terms of impacting on existing regime structures such as provision of warm water, electricity generation or the typical usage of cars. In order to achieve such an upscaling and growth they are all characterised by particular patterns and phases of development as well as typical patterns of innovation system functions. Grassroots initiatives were of particular importance in the early phases of development and provided particular forms of shielding and empowering of these niches-by providing legitimacy to these developments, linking them to broader societal discourses and movements 
(anti-nuclear, limits of growth, Waldsterben) and by bringing in particular sorts of resources such as unpaid working time or pre-existing local structures and networks. These resources helped to maintain the momentum of further development and dissemination of these innovations despite a lack of competitiveness with existing technologies. A crucial step for the further development and growth of these innovations was then the successful restructuring of the niche or innovation system by shifting from a grassroots innovation mode to a more traditional firms and economics based one. Entrepreneurial activities moved to the foreground, the formation of commercial markets and extension of the knowledge base in cooperation with R\&D institutions. During this modal shift grassroots movements rather became a source of start-up companies and continued their activities of lobbying for political and institutional support of these sustainable innovations.

The comparison also shows how much the development of grassroots activities depends on a variety of specific contextual conditions (i.e., conditions that are not to be directly influenced by local actors). We can see a common pattern in our cases of recent and widely discussed environmental problems and strong interlinkages with the environmental movement of the 1970s along with specific, regionally pre-existing conditions such as the long tradition of advancement in wind energy in Denmark, the high proportion of old wood-fired heaters in Austria, or the deep-rooted presence of cooperatives in Switzerland. However, grassroots activities start off when homogeneously perceived global problems interfere with specific combinations of structural conditions provided in local niches. Another common characteristic of the studied cases is that the activities are driven by a wide array of motives ranging from expected individual benefits for participants to public goods or mission-oriented motives. In all three cases, the activities have resulted in democratic, not-for-profit structures that provide open access to all interested parties-including actors with commercial interests - and knowledge that for a long time was freely available. The grassroots activities in the cases studied here were successful in articulating and transferring alternative worldviews jointly with specific user needs and expectations to technological and/or organisational solutions that were previously neglected by traditional market actors. New solutions were tested and improved in highly motivated and committed user communities in early phases of development which finally resulted in technically and socially stable solutions.

Contrary to other types of innovation niches, like market-based or science-based contexts, grassroots innovations stand out due to an innovation culture based on democracy, openness, diversity, practical experimentation, social learning, and negotiation. A culture that is attractive for and reproduced by a broad variety of civil society actors mobilising and bringing together a distinctive combination of knowledge, comprising local embedded, practical, artisan, technological, scientific, and cosmological (i.e. wider orientations and worldviews) forms of knowledge. Due to the grassroots nature of these niches solutions have to be developed in a bottom-up fashion, step by step after assessing positive as well as negative practical experiences. In doing so they fairly good provide what in the context of constructive technology assessment is called broadening and enriching the design (Van Merkerk and Smits, 2008), helping to avoid one-sided technological or commercial biases 
early on and resulting in solutions that are appropriated to local use contexts from the beginning.

For theory building in the field of grassroots innovations it is important to point out that the examples studied in this paper can be labelled as single-issue initiatives, in contrast to forms of grassroots innovations applying a community development approach (like the Local Agenda 21 or the Transition Towns movement) and therefore have to focus on a multiplicity of problems and solutions. Those multi-issue initiatives are confronted with a much more diverse and complex starting position and we may expect that a focus on the community level and the limitation on locally available resources to a large extent makes it difficult to create innovation niches that can grow and operate for a longer period of time. Recent research has shown that even larger municipalities face a number of problems to serve as stable incubators for sustainable solutions (Schreuer et al., 2010).

The main aim of this paper was to provide a comparative picture of the dynamics of successful grassroots initiatives over longer periods of time. On a general level we may conclude that the temporal development shows some critical phases that have to be overcome and consequently lead to new niche characteristics. One of these critical steps seems to be the transition from loose networks of friends and other interested people to more formalised forms of organisations. Another step at the end of the lifetime of the grassroots initiatives occurred from not-for-profit and voluntary engagement towards more professionalised and/or profit oriented settings. Main drivers of these developments were growing demand for technologies and services provided by the initiatives and the willingness of new participants to be part of and/or to contribute to the ongoing activities. We also have seen that niches have grown interdependently with the development of their respective outcomes. Solutions derived either became black-boxed working business models (car sharing) or have been translated and modified by a variety of actors to new contexts (offshore wind turbines).

The three cases of environmental innovations discussed in this article have gained global reach, gave rise to new industries and have the potential to be crucial elements of more sustainable energy and transport systems. They all had at least part of their roots and foundational phase in civil society and grassroots movements. It is very likely that wind energy or solar thermal collectors also would have been developed without the influence of these grassroots innovations, but without doubt grassroots initiatives contributed significantly to a speeding up of the development and dissemination process in the early phases of sustainable innovations and shaped the design as well as specific socio-technical development paths. Grassroots and commercial innovations do not exclude each other but rather have complementary strengths and impediments and may dominate different phases of the innovation journey, up-scaling and diffusion of new environmental technologies and services. However, the important contribution of grassroots innovations for change towards more sustainable systems of production and consumption has not been given sufficient credit in science or policy making.

One interesting direction for future research is to better understand the starting conditions for grassroots innovations. Whereas our comparison of successful cases was able to show the importance of specific combinations of locally available pre-conditions future 
research should focus on missed opportunities and discontinued initiatives to discuss the role of local settings and structural conditions from a contrasting point of view. Since we may expect that the potential for bottom-up contributions to more sustainability is enormous in terms of issues, ideas and numbers of initiatives research in this direction could help to improve our ability to gain better societal profit out of it. In this context it would also be important to improve our understanding on how to deal with social diversity in pioneering groups as it turned out in our cases, that the composition of pioneering networks turned out to be a major source to shape sustainable innovation in early phases. More over it seems to be promising to focus on hybrid-modes of innovation and investigate conditions for broadening niches from different sides applying different norms and rationalities. Our cases suggest that broadening was actively welcomed or at least widely tolerated by grassroots actors, but our knowledge about the strategies of other main innovation actors (industry, research) is very limited in this respect. Another interesting direction for future research is the relation incumbent regimes and niches facilitated by grassroots innovations. In our cases it seems that powerful regime actors tend to ignore those activities on the fringes. However, we may assume that in other, less successful cases of grassroots activities, regime actors did play a much more active role. All in all, a better understanding of the pre-conditions, contexts and dynamics of grassroots innovations can help us broaden one-sided innovation policies and develop more supportive conditions for grassroots innovations for sustainability.

\section{References}

Akrich, M., 1995, User representations: practices, methods and sociology, in: Rip, A., Misa, T. J. and Schot, J. (Eds): Managing technology in society: the approach of constructive technology assessment, London: Cassell, 167-184.

Behrendt, S., 2000, Car-Sharing: Nachhaltige Mobilität durch eigentumslose Pkw-Nutzung?, Berlin: Institut für Zukunftsstudien und Technologiebewertung (IZT).

Carlsson, B., Stankiewicz, R., 1991, On the nature, function, and composition of technological systems, Journal of Evolutionary Economics 1, 93-118.

Daimler AG, 2012, Mobility Concepts: car2go [Accessed on: 07/13 2012] $<$ http://www.daimler.com/dccom/0-5-1392621-1-1392612-1-0-0-0-0-0-7751-7165-0$0-0-0-0-0-0 . h t m l>$.

Danielsen, O. and Halkier, B., 1995, Renewable energy in the danish energy system: from small experiments to full scale energy plants. The Danish national report of the Express Path project: Roskilde University.

Dewald, U. and Truffer, B., 2012, The Local Sources of Market Formation: Explaining Regional Growth Differentials in German Photovoltaic Markets, European Planning Studies 20(3), 397-420.

Eyerman, R. and Jamison, A., 1991, Social movements: a cognitive approach, University Park, Pa.: Pennsylvania State University Press.

Faninger, G., 2000, Der Solarmarkt in Österreich 2000 (Kurzfassung), Klagenfurt/Wien: Bundesverband Solar in der Wirtschaftskammer Österreich.

Garud, R. and Karnøe, P., 2003, Bricolage versus breakthrough: distributed and embedded agency in technology entrepreneurship, Research Policy 32, 277-300.

Geels, F., 2011, The multi-level perspective on sustainability transitions: Responses to seven criticisms, Environmental Innovation and Societal Transitions 1, 24-40. 
Geels, F. and Raven, R., 2006, Non-linearity and Expectations in Niche-Development Trajectories: Ups and Downs in Dutch Biogas Development (1973-2003), Technology Analysis \& Strategic Management 18(3/4), 375-392.

Haas, R., Berger, M. and Kranzl, L., 2001, Strategien zur weiteren Forcierung erneuerbarer Energieträger in Österreich unter besonderer Berücksichtigung des EU-Weißbuches für Erneuerbare Energien und Campaign for Take-off, commissioned by: BMLFUW, B. u., Wien.

Haefeli, U., Matti, D., Schreyer, C. and Maibach, M., 2006, Evaluation Car-Sharing Bern: Bundesamt für Energie BFE.

Hess, D. J., 2007, Alternative pathways in science and industry: activism, innovation, and the environment in an era of globalization; in series: Urban and industrial environments, Cambridge, Mass.: MIT Press.

Hockerts, K., 2004, Mobility Car-Sharing (B): The Moment of Confrontation, commissioned by: INSEAD, Fountainbleau.

Hodson, M. and Marvin, S., 2010, Can cities shape sociotechnical transitions and how would we know if they were?, Research Policy 39, 477-485.

Hoogma, R., Kemp, R., Schot, J., Truffer, B. and Banister, D., 2002, Experimenting for sustainable transport: the approach of strategic niche management, Vol. Transport, Development and Sustainability, London: Spon Press.

Jacobsson, S., Johnson, A., 2000, The diffusion of renewable energy technology: an analytical framework and key issues for research, Energy Policy 28 (9), 625-640.

Jorgensen, U. and Karnøe, P., 1995, The Danisch wind-turbine story: technical solutions to political visions?, in: Rip, A., Misa, T. J. and Schot, J. (Eds): Managing technology in society: the approach of constructive technology assessment, London: Cassell, 57-82.

Kemp, R., Schot, J. and Hoogma, R., 1998, Regime Shifts to Sustainability Through Processes of Niche Formation: The Approach of Strategic Niche Management, Technology Analysis \& Strategic Management 10(2), 175-195.

Mackay, H. and Gillespie, G., 1992, Extending the social shaping of technology approach: ideology and appropriation, Social Studies of Science 22, 685-716.

Markard, J., Truffer, B., 2008, Technological innovation systems and the multi-level perspective: towards an integrated framework, Research Policy 37, 596-615.

Mobility car sharing, 2011, Die Geschichte des Carsharing <http://www.mobility.ch/files/ pdf1/Geschichte1.pdf>.

Negro, S., Suurs, R., Hekkert, M., 2008, The bumpy road of biomass gasification in the Netherlands: Explaining the rise and fall of an emerging innovation system, Technological Forecasting and Social Change 75 (1), 57-77.

Observ'ER, Eclareon, “Jozef Stefan” Institute, Energy research Centre of the Netherlands and Institute for Renewable Energy, 2008, The state of renewables energies in Europe. 8th EurObserv'ER Report, Paris.

Ornetzeder, M., 2001, Old technology and social innovations: inside the Austrian success story on solar water heaters, Technology Analysis and Strategic Management 13(1), 112-115.

Ornetzeder, M. and Rohracher, H., 2006, User-led innovations and participation processes: lessons from sustainable energy technologies, Energy Policy 34(2), 138-150.

OTS/BMVIT, 2012, Bures: Größte thermische Solaranlage der Welt mit Technologie aus Österreich <http://www.ots.at/presseaussendung/OTS_20120410_OTS0089/buresgroesste-thermische-solaranlage-der-welt-mit-technologie-aus-oesterreich>.

Oudshoorn, N. and Pinch, T., 2008, User-technology relationships: some recent developments, in: Hackett, E. J., Amsterdamska, O., Lynch, M. and Wajcman, J. (Eds): The handbook of science and technology studies, Cambridge, Mass.: MIT Press, 541-565. 
Rip, A. and Kemp, R., 1998, Technological change, in: Rayner, S. and Malone, E. L. (Eds): Human choice and climate change: resources and technology, Columbus, Ohio: Batelle Press, 327-399.

Russell, S. and Williams, R., 2002, Social shaping of technology: frameworks, findings and implications for policy with glossary of social shaping concepts, in: Sørensen, K. H. and Williams, R. (Eds): Shaping Technology, Guiding Policy: Concepts, Spaces and Tools, Cheltenham: Edward Elgar, 37-131.

Schot, J. and Geels, F., 2007, Niches in evolutionary theories of technical change: A critical survey of the literature, Journal of Evolutionary Economics 17(5), 605-622.

Schot, J. and Geels, F. W., 2008, Strategic niche management and sustainable innovation journeys: theory, findings, research agenda, and policy, Technology Analysis \& Strategic Management 20(5), 537-554.

Schreuer, A., Ornetzeder, M. and Rohracher, H., 2010, Negotiating the local embedding of socio-technical experiments: a case study in fuel cell technology, Technology Analysis \& Strategic Management 22(6), 729-743.

Seyfang, G. and Haxeltine, A., 2012, Growing grassroots innovations: exploring the role of community-based initiatives in governing sustainable energy transitions, Environment and Planning C: Government and Policy 30, 381-400.

Seyfang, G. and Smith, A., 2007, Grassroots innovations for sustainable development: Towards a new research and policy agenda, Environmental Politics 16(4), 584-603.

Shaheen, S., Sperling, D. and Wagner, C., 1998, Carsharing in Europe and North America: Past, Present and Future Transportation Quarterly 52(3), 35-52.

Sine, W. D. and Lee, B. H., 2009, Tilting at Windmills? The Environmental Movement and the Emergence of the U.S. Wind Energy Sector, Administrative Science Quarterly March 54, 123-155.

Smith, A., 2007, Translating Sustainabilities between Green Niches and Socio-Technical Regimes, Technology Analysis \& Strategic Management 19(4), 427-450.

Smith, A. and Raven, R., 2012, What is protective space? Reconsidering niches in transitions to sustainability Research Policy 41, 1025-1036.

Toffler, A., 1980, The third wave, New York: Bentam Books.

Tranaes, F., 1997, Danish Wind Energy <http://www.dkvind.dk/eng/publications/danish_ wind_energy.pdf >.

Truffer, B., 2003, User Led innovation processes: the development of professional carsharing by environmentally concerned citizen, Innovation - The European Journal of Social Science Research 16(2), 139-154.

Truffer, B. and Coenen, L., 2012, Environmental innovation and sustainability transitions in regional studies, Regional Studies 46(1), 1-21.

Van Merkerk, R. O. and Smits, R. E. H. M., 2008, Tailoring CTA for emerging technologies, Technological Forecasting and Social Change 75(3), 312-333.

Verein für Konsumenteninformation, 1977, Marktübersicht thermische Solaranlagen, Konsument, 3-7.

Von Hippel, E., 1998, Economics of product development by users: the impact of "sticky" local information, Management Science 44(5), 629-644.

Weiss, W. and Mauthner, F., 2010, Solar Heat Worldwide. Markets and Contribution to the Energy Supply 2008, commissioned by: Programme, I. S. H. C.

Wenger, E., 1998, Communities of practice: learning, meaning and identity, Cambridge: Cambridge University Press.

Weyer, J., 2006, Path-making by actor networks: the case of the winged space plane, EIASM Workshop "Organizing Paths - Paths of Organizing", Berlin.

Weyer, J., Kirchner, U., Riedl, L. and Schmidt, J. F. K., 1997, Technik, die Gesellschaft schafft: Soziale Netzwerke als Ort der Technikgenese, Berlin: edition sigma. 